\title{
WYKAZ ORZECZNICTWA SĄDÓW UNIJNYCH W SPRAWACH ŚRODOWISKA I JEGO OCHRONY ZA OKRES WRZESIEŃ 2012-GRUDZIEŃ 2013
}

\section{EU CASE LAW ON THE ENVIRONMENT AND ITS PROTECTION: SEPTEMBER 2012-DECEMBER 2013}

http://dx.doi.org/10.12775/PPOS.2013.025

\section{Słowa kluczowe}

Prawo ochrony środowiska; orzecznictwo sądów unijnych; wykładnia prawa.

\section{Keywords}

Environmental law; EU case law; legal interpretation.

Doktor nauk prawnych, adiunkt w Katedrze Prawa Ochrony Środowiska Wydziału Prawa i Administracji Uniwersytetu Mikołaja Kopernika w Toruniu. 


\section{WPROWADZENIE}

Sporządzenie wykazu orzecznictwa sądów unijnych w sprawach środowiska i jego ochrony za okres wrzesień 2012-grudzień 2013 ma na celu przedstawienie w syntetyczny sposób najważniejszych zagadnień dotyczących aktualnie kształtowanej wykładni unijnego prawa ochrony środowiska.

W omawianym okresie - wrzesień 2013-grudzień 2013 wyszczególnić można 31 wyroków (wydanych przede wszystkim przez Trybunał), które ujęto w następujących blokach tematycznych („Gospodarka odpadami” - 10 orzeczeń; „Ocena oddziaływania na środowisko” - 3 orzeczenia; „Partycypacja społeczeństwa w ochronie środowiska” - 5 orzeczeń; „Ochrona przyrody” - 2 orzeczenia; "Ochrona klimatu” - 3 orzeczenia; "Ochrona wód” - 4 orzeczenia; "Ochrona powietrza” - 2 orzeczenia; „Zagadnienia pozostałe” - 2 orzeczenia). Zaznaczyć należy, że podział ten ma charakter pomocniczy, a oparty został $\mathrm{z}$ jednej strony na kryterium aktu normatywnego, stanowiącego przedmiot analiz w sprawie, zaś z drugiej strony - na kryterium przedmiotowej kwalifikacji dokonanej $\mathrm{w}$ ramach repertorium orzecznictwa Trybunału Sprawiedliwości UE.

Biorąc pod uwagę tryb postępowania można wskazać, że w ujętej grupie 18 orzeczeń wydanych zostało w trybie pytań prejudycjalnych, zaś $12 \mathrm{w}$ postępowaniu o uchybienie przez państwo członkowskie zobowiązaniom traktatowym (art. 258 TFUE). Jedno orzeczenie (wyrok Sądu z dnia 7 marca 2013 r. w sprawie T-370/11 Polska przeciwko Komisji - skarga oddalona), wydane zostało $\mathrm{w}$ postępowaniu o stwierdzenie nieważności decyzji Komisji 2011/278/UE z dnia 27 kwietnia 2011 r. w sprawie ustanowienia przejściowych zasad dotyczących zharmonizowanego przydziału bezpłatnych uprawnień do emisji w całej Unii na mocy art. 10a dyrektywy 2003/87/WE Parlamentu Europejskiego i Rady.

Warto też zwrócić uwagę na fakt, że w grupie orzeczeń zapadłych $\mathrm{w}$ omawianym okresie znalazły się 3 orzeczenia, wydane przez Trybunał w składzie wielkiej izby. Są to wyro-

4/2013 ki: z dnia 11 września 2012 r. w sprawie C-43/10 Nomarchiaki 
Aftodioikisi Aitoloakarnanias i in. przeciwko Ypourgos Perivallontos $i$ in. (dotyczący planów gospodarowania wodami w dorzeczach, projektu przekierowania wód i obszarów Natura 2000), z dnia 15 stycznia 2013 r. w sprawie C-416/10 Jozef Križan $i$ in. przeciwko Slovenská inšpekcia životného prostredia (dotyczący udziału społeczeństwa $\mathrm{w}$ procesach decyzyjnych) oraz $\mathrm{z}$ dnia 19 grudnia 2013 r. w sprawie C-279/12 Fish Legal i Emily Shirley przeciwko Information Commissioner $i$ inni (dotyczący dostępu do informacji o środowisku oraz pojęcia „organu władzy publicznej").

Zapadłe w omawianym okresie orzeczenia zostały zaprezentowane według następującego wzorca: data wydania, numer sprawy, strony, przedmiot sprawy oraz sentencja. Wszystkie elementy podane zostały w języku polskim, w oficjalnym tłumaczeniu zaczerpniętym przede wszystkim z polskiej wersji Dziennika Urzędowego UE seria C. Jednakże, w przypadku niektórych orzeczeń, sięgnięto po oficjalne tłumaczenie w języku polskim udostępnione w serwisie „InfoCuria - Orzecznictwo Trybunału Sprawiedliwości", jako jedyne dostępne z uwagi na stosunkowo krótki upływ czas od chwili ich opublikowania do momentu ujęcia tych orzeczeń w niniejszym wykazie.

\section{TEZY ORZECZEŃ}

\subsection{GOSPODARKA ODPADAMI}

\subsubsection{Wyrok Trybunału z dnia 4 października 2012 r. w sprawie C-391/11 Komisja Europejska przeciwko Królestwu Belgii ${ }^{1}$}

Przedmiot: uchybienie zobowiązaniom państwa członkowskiego; brak wydania w terminie przepisów niezbędnych do zastosowania się do przepisów art. 2 pkt 1 i 3 oraz art. 5 ust. 1, 2 i 4 dyrektywy Parlamentu Europejskiego i Rady 2000/53/WE

1 Dz.Urz. UE C 366 z 24.11.2012. 
z dnia 18 września 2000 r. w sprawie pojazdów wycofanych z eksploatacji (Dz.U. L 269, s. 34); pojęcie pojazdu i producenta; wprowadzenie dodatkowych, nieprzewidzianych w dyrektywie przesłanek bezpłatnego wycofania pojazdu z eksploatacji.

Sentencja:

1) Skarga zostaje oddalona.

2) Komisja Europejska i Królestwo Belgii pokrywają własne koszty.

\subsubsection{Wyrok Trybunału z dnia 18 października 2012 r.}

w sprawie C-301/10 Komisja Europejska przeciwko Zjednoczonemu Królestwu Wielkiej Brytanii i Irlandii Pótnocnej ${ }^{2}$

Przedmiot: uchybienie zobowiązaniom państwa członkowskiego; naruszenie art. 3 ust. 1 i 2, art. 4 ust. 1 i 3 oraz art. 10 a także załącznika I A i B dyrektywy Rady z dnia 21 maja 1991 r. dotyczącej oczyszczania ścieków komunalnych (91/271/EWG) (Dz.U. L 135, s. 40); brak zapewnienia odpowiedniego oczyszczania ścieków komunalnych w wielu aglomeracjach Londynu (Whitburn, Beckton, Crossness i Mogden)

Sentencja:

1) Nie zapewniając:

- odpowiednich systemów zbierania ścieków komunalnych z aglomeracji o równoważnej liczbie mieszkańców ponad 15000 w Sunderlandzie (Whitburn) oraz w Londynie (systemy zbierania $w$ Beckton $i w$ Crossness) zgodnie z art. 3 ust. 1 i 2 oraz z pkt A załącznika I do dyrektywy Rady 91/271/EWG z dnia 21 maja 1991 r. dotyczacej oczyszczania ścieków komunalnych oraz

- odpowiedniego oczyszczania ścieków komunalnych z aglomeracji o równoważnej liczbie mieszkańców ponad $15000 w$ Londynie (oczyszczalnie $w$ Beckton, $w$ Crossness i w Mogden) zgodnie z art. 4 ust. 1 i 3, art. 10 oraz z pkt B załacznika I do dyrektywy 91/271, 
Zjednoczone Królestwo uchybiło zobowiązaniom ciażacym na nim na podstawie tej dyrektywy.

2) Zjednoczone Królestwo zostaje obcią̇one kosztami postępowania.

\subsubsection{Wyrok Trybunału z dnia 19 grudnia 2012 r. w sprawie C-374/11 Komisja Europejska przeciwko Irlandii ${ }^{3}$}

Przedmiot: uchybienie zobowiązaniom państwa członkowskiego; niewykonanie wyroku Trybunału z dnia 29 października 2009 r. w sprawie C-188/08 Komisja przeciwko Irlandii dotyczący naruszenia art. 4, 7, 8, 9,10, 11, 12, 13 i 14 dyrektywy Rady 75/442/EWG z dnia 15 lipca 1975 r. w sprawie odpadów (Dz.U. L 194, s. 39), zmienionej dyrektywą Rady 91/156/EWG z dnia 18 marca 1991 r. (Dz.U. L 78, s. 32) w odniesieniu do ścieków domowych usuwanych na terenach wiejskich poprzez szamba; odpady nieobjęte inną legislacją; żądanie nałożenia okresowej kary pieniężnej oraz ryczałtu.

Sentencja:

1) Nie podejmując wszelkich środków koniecznych do wykonania wyroku Trybunału z dnia 29 października 2009 r. w sprawie C-188/08 Komisja przeciwko Irlandii stwierdzajaceego uchybienie przez Irlandię obowiazkom wynikajacym z art. 4 i 8 dyrektywy Rady 75/442/EWG z dnia 15 czerwca 1975 r. w sprawie odpadów zmienionej dyrektywa Rady 91/156/EWG z dnia 18 marca 1991 r. to państwo członkowskie uchybito zobowiazaniom, które na nim ciąż na mocy art. 260 ust. 1 TFUE.

2) Irlandia zostaje zobowiazana do zaptacenia na rzecz Komisji Europejskiej na rachunek „Zasoby własne Unii Europejskiej" okresowej kary pieniężnej w kwocie 12000 EUR za każdy dzień zwłoki w podjęciu środków koniecznych do zastosowania się do ww. wyroku w sprawie Komisja przeciwko Irlandii, poczquszy od dnia ogłoszenia niniej-

${ }^{3}$ Dz.Urz. UE C 046 z 16.02.2013. 
szego wyroku do dnia wykonania ww. wyroku $w$ sprawie Komisja przeciwko Irlandii.

3) Irlandia zostaje zobowiazana do wpłacenia na rzecz Komisji Europejskiej na rachunek „Zasoby własne Unii Europejskiej" ryczattowej kwoty 2000000 EUR.

4) Irlandia zostaje obciązona kosztami postępowania.

\subsubsection{Wyrok Trybunału z dnia 7 marca 2013 r. w sprawie C-358/11 \\ Lapin elinkeino-, liikenne- ja ympäristökeskuksen liikenne ja infrastruktuuri-vastuualue 4 \\ (wniosek o wydanie orzeczenia w trybie prejudycjalnym złożony przez Korkein hallinto-oikeus-Finlandia)}

Przedmiot: wykładnia dyrektywy Parlamentu Europejskiego i Rady 2008/98/WE z dnia 19 listopada 2008 r. w sprawie odpadów oraz uchylającej niektóre dyrektywy (Dz.U. L 312, s. 3) i rozporządzenia (WE) nr 1907/2006 Parlamentu Europejskiego i Rady z dnia 18 grudnia 2006 r. w sprawie rejestracji, oceny, udzielania zezwoleń i stosowanych ograniczeń w zakresie chemikaliów (REACH) i utworzenia Europejskiej Agencji Chemikaliów, zmieniającego dyrektywę 1999/45/WE oraz uchylającego rozporządzenie Rady (EWG) nr 793/93 i rozporządzenie Komisji (WE) nr 1488/94, jak również dyrektywę Rady 76/769/EWG i dyrektywy Komisji 91/155/EWG, 93/67/EWG, 93/105/WE i 2000/21/WE; rejestracja, ocena i udzielanie zezwoleń w zakresie chemikaliów; substancja objęta ograniczeniem na podstawie załącznika XVII do tego rozporządzenia; wykorzystanie starych masztów telefonicznych zabezpieczonych roztworem CCA (miedź-chrom-arsen) do podbudowy ścieżki.

Sentencja:

1) Prawo Unii nie wyklucza co do zasady tego, aby odpad uznany za niebezpieczny mógt przestać być odpadem $w$ rozumieniu dyrektywy 2008/98/WE Parlamentu Europejskiego i Rady z dnia 19 listopada 2008 r. w sprawie 
odpadów oraz uchylającej niektóre dyrektywy, jeśli proces odzysku powala uczynić go zdatnym do użytku bez stwarzania zagrożenia dla zdrowia człowieka i bez wyrzadzania szkody środowisku naturalnemu, a ponadto jeżeli nie stwierdzono, że posiadacz tego przedmiotu pozbywa się go, zamierza się go pozbyć lub został zobowiązany do pozbycia się go $w$ rozumieniu art. 3 pkt 1 tej dyrektywy, przy czym okoliczności te powinien zbadać sąd odsyłający.

2) Rozporządzenie (WE) nr 1907/2006 Parlamentu Europejskiego i Rady z dnia 18 grudnia 2006 r. w sprawie rejestracji, oceny, udzielania zezwoleń $i$ stosowanych ograniczeń $w$ zakresie chemikaliów (REACH), utworzenia Europejskiej Agencji Chemikaliów, zmieniające dyrektywe 1999/45/WE oraz uchylajace rozporzadzenie Rady (EWG) $n r$ 793/93 i rozporzadzenie Komisji (WE) $n r$ 1488/94, jak również dyrektywę Rady 76/769/EWG i dyrektywy Komisji 91/155/EWG, 93/67/EWG, 93/105/ WE i 2000/21/WE, $w$ brzmieniu zmienionym rozporzadzeniem Komisji (WE) nr 552/2009 z dnia 22 czerwca 2009 r., a w szczególności jego załącznik XVII - w zakresie, $w$ jakim dopuszcza on pod pewnymi warunkami stosowanie drewna zabezpieczonego roztworem zwanym "CCA” (zawierajacym miedź, chrom $i$ arsen) - ma $w$ okolicznościach takich jak rozpatrywane $w$ postępowaniu głównym znaczenie dla ustalenia, czy drewno takie może przestać być odpadem dlatego, że jego posiadacz, $w$ razie spetnienia tych warunków, nie jest zobowiąany do pozbycia się go $w$ rozumieniu art. 3 pkt 1 dyrektywy 2008/98.

3) Artykuty 67 i 128 rozporządzenia nr 1907/2006 $w$ brzmieniu zmienionym rozporzadzeniem $\mathrm{nr}$ 552/2009 należy interpretować $w$ ten sposób, że $w$ prawie Unii zharmonizowane zostały wymogi dotyczace produkcji, wprowadzania do obrotu i stosowania substancji takiej jak substancja zawierajacca związki arsenu, która jest objęta ograniczeniem na podstawie załacznika XVII do tego rozporządzenia.

4) Punkt 19 ust. 4 lit. b) załacznika XVII do rozporządzenia $n r$ 1907/2006 $w$ brzmieniu zmienionym rozporzadze- 
niem $\mathrm{nr}$ 552/2009, wymieniajacy sposoby, w jakie - tytułem odstępstwa - może być używane drewno zabezpieczone roztworem zwanym "CCA” (zawierajacym miedź, chrom $i$ arsen), należy interpretować $w$ ten sposób, $\dot{z} e$ zawarte $w$ tym przepisie wyliczenie ma charakter wyczerpujacy, wobec czego rzeczonego odstęstwa nie można stosować do sytuacji innych niż te, które zostały $w$ nim przewidziane. Zadaniem sqadu odsyłajacego jest zbadanie, czy $w$ okolicznościach takich jak te zachodzace $w$ postępowaniu głównym wykorzystanie masztów telefonicznych jako podbudowy ścieżek mieści się $w$ ramach wymienionych $w$ tym przepisie zastosowań.

5) Uregulowania zawarte $w$ pkt 19 ust. 4 lit. d) tiret drugie załacznika XVII do rozporządzenia nr 1907/2006 $w$ brzmieniu zmienionym rozporzadzeniem $\mathrm{nr}$ 552/2009, $w$ myśl których drewno zabezpieczone roztworem zwanym „CCA” (zawierajacym miedź, chrom $i$ arsen) nie może być stosowane, gdy tylko powstaje ryzyko wielokrotnego kontaktu ze skóra, należy interpretować $w$ ten sposób, że analizowany zakaz powinien mieć zastosowanie $w$ każdej sytuacji, $w$ której wedle wszelkiego prawdopodobieństwa może dojść do wielokrotnego kontaktu skóry z tak zabezpieczonym drewnem, przy czym owo prawdopodobieństwo należy określić na podstawie konkretnych warunków, w jakich zwykle używane ma być zastosowane drewno. Dokonanie oceny tych warunków jest zadaniem sq̨du odsyłającego.

\subsubsection{Wyrok Trybunału z dnia 25 kwietnia 2013 r. w sprawie C-331/11 Komisja Europejska przeciwko Republice Stowackiej ${ }^{5}$}

Przedmiot: uchybienie zobowiązaniom państwa członkowskiego, naruszenie art. 14 lit. a), b) i c) dyrektywy Rady 1999/31/WE z dnia 26 kwietnia 1999 r. w sprawie składowania odpadów (Dz.U. L 182, s. 1); dalsze prowadzenie działalności 
przez składowisko odpadów Žilina-Považský Chlmec pomimo braku planu uzdatniania terenu,

Sentencja:

1) Republika Stowacka uchybiła zobowiązaniom ciążacym na niej na mocy art. 14 lit. a)-c) dyrektywy Rady 1999/31/ WE z dnia 26 kwietnia 1999 r. w sprawie składowania odpadów ze względu na to, i̇z zezwoliła na prowadzenie składowiska odpadów Žilina - Považský Chlmec bez sporządzenia planu uzdatniania terenu tego składowiska oraz bez wydania ostatecznej decyzji w przedmiocie tego, czy to składowisko to może nadal prowadzić swa działalność na podstawie przyjętego planu uzdatniania.

2) Republika Stowacka zostaje obciażona kosztami postępowania.

\subsubsection{Wyrok Trybunału z dnia 17 października 2013 r. w sprawie Komisja Europejska przeciwko Królestwu Belgii ${ }^{6}$}

Przedmiot: Uchybienie zobowiązaniom państwa członkowskiego; niepełne wykonanie wyroku Trybunału z dnia 8 lipca 2004 r. w sprawie C-27/03 Komisja przeciwko Belgii (niepublikowanego w Zbiorze) dotyczącego braku transpozycji w wyznaczonym terminie przepisów dyrektywy Rady 91/271/ /EWG z dnia 21 maja 1991 r. dotyczącej oczyszczania ścieków komunalnych (Dz.U. L 135, s. 40); naruszenie art. 3 ust. 1 zdanie drugie i art. 5 ust. 2 i 3 wspomnianej dyrektywy; obliczanie kar: łączna zapłata ryczałtu i okresowej kary pieniężnej.

Sentencja:

1) Nie podejmując wszystkich środków koniecznych do wykonania wyroku z dnia 8 lipca 2004 r. w sprawie C-27/03 Komisja przeciwko Belgii, w którym Trybunał stwierdzit, że Królestwo Belgii uchybiło zobowiązaniom wynikającym z art. 3 i 5 dyrektywy Rady 91/271/EWG z dnia 21 maja 1991 r. dotyczacej oczyszczania ścieków komunalnych, zmienionej dyrektywa Komisji 98/15/WE z dnia 27 lute-

6 Dz.Urz. UE C 367 z 14.12.2013. 
go 1998 r., wspomniane państwo członkowskie uchybiło zobowiązaniom, które cią̇̇a na nim na mocy art. 260 ust 1 TFUE.

2) Królestwo Belgii jest zobowiązane do zapłacenia na rzecz Komisji Europejskiej, na rachunek "Środki własne Unii Europejskiej", ryczałtu w wysokości $10 \mathrm{mln}$ EUR.

3) Jeżeli uchybienie stwierdzone w pkt 1 będzie trwało $w$ dniu ogłoszenia niniejszego wyroku, Królestwo Belgii będzie zobowiazane do zapłacenia na rzecz Komisji Europejskiej, na rachunek „Środki własne Unii Europejskiej”, okresowej kary pieniężnej w wysokości 859404 EUR za każde pół roku zwłoki we wdrażaniu środków koniecznych do zastosowania się do ww. wyroku w sprawie Komisja przeciwko Belgii, liczac od dnia ogłoszenia niniejszego wyroku $a \dot{z}$ do chwili petnego wykonania ww. wyroku $w$ sprawie Komisja przeciwko Belgii, przy czym faktyczna kwota tej okresowej kary pieniężnej winna zostać obliczona pod koniec każdego okresu sześciomiesięcznego poprzez odjęcie od całkowitej wartości za taki okres wartości procentowej wyrażającej proporcję równoważnej liczby mieszkańców, której zapewniono zgodność z ww. wyrokiem $w$ sprawie Komisja przeciwko Belgii przed końcem takiego okresu, do równoważnej liczby mieszkańców, która nie jest zgodna z niniejszym wyrokiem $w$ dniu jego ogłoszenia.

4) Królestwo Belgii zostaje obciązone kosztami postępowania.

5) Zjednoczone Królestwo Wielkiej Brytanii i Irlandii Pótnocnej pokrywa własne koszty. 


\subsubsection{Wyrok Trybunału z dnia 3 października 2013 r. w sprawie C-113/12 Donal Brady przeciwko Environmental Protection Agency ${ }^{7}$ (wniosek o wydanie orzeczenia $\mathrm{w}$ trybie prejudycjalnym złożony przez Supreme Court, Irlandia)}

Przedmiot: środowisko naturalne; dyrektywa 75/442/ EWG; gnojowica świńska wytworzona i składowana w gospodarstwie hodowli trzody chlewnej do momentu sprzedaży podmiotom prowadzącym gospodarstwa rolne, które wykorzystują ją jako nawóz na swoim terenie; kwalifikacja jako odpady lub produkt uboczny; przesłanki; ciężar dowodu; dyrektywa 91/676/EWG; brak transpozycji; odpowiedzialność osobista producenta za przestrzeganie prawa Unii dotyczącego odpadów i nawozów przez takie podmioty.

Sentencja:

1) Artykut 1 lit. a) akapit pierwszy dyrektywy Rady 75/442/ EWG z dnia 15 lipca 1975 r. w sprawie odpadów, zmienionej decyzją Komisji 96/350/WE z dnia 24 maja 1996 r., należy interpretować $w$ ten sposób, że gnojowica wytworzona $w$ gospodarstwie intensywnej hodowli trzody chlewnej i składowana do czasu jej dostarczenia rolnikom $w$ celu jej u̇̇ycia przez nich jako nawozu na ich gruntach nie stanowi „odpadów” w rozumieniu tego przepisu, lecz produkt uboczny, jeżeli producent zamierza sprzedać ja później na korzystnych dla siebie warunkach ekonomicznych, pod warunkiem że ponowne wykorzystanie gnojowicy jest nie tylko możliwe, lecz pewne, nie wymaga jakiegokolwiek wstępnego przetwarzania i stanowi kontynuacje procesu produkcji. Sądy krajowe musza sprawdzić, uwzględniając wszystkie istotne okoliczności charakteryzujace zawiste przed nimi sprawy, czy te różne kryteria zostały spetnione.

2) Prawo Unii nie sprzeciwia się temu, aby na producencie gnojowicy spoczywat ciężar wykazania, iż spetnione zostały kryteria pozwalające stwierdzić, że substancja taka

7 http://curia.europa.eu 
jak gnojowica produkowana, składowana i sprzedawana $w$ okolicznościach takich jak $w$ postępowaniu głównym stanowi produkt uboczny, o ile nie prowadzi to do naruszenia skuteczności tego prawa, a zwłaszcza dyrektywy 75/442, oraz zapewnione zostanie przestrzeganie zobowiazań wynikajacych z tego prawa, a zwtaszcza obowiązku niepodporządkowywania przepisom tej dyrektywy substancji, które $w$ zastosowaniu rzeczonych kryteriów należy uznać zgodnie z orzecznictwem Trybunału za produkty uboczne, do których dyrektywa ta nie ma zastosowania.

3) Artykut 2 ust. 1 lit. b) ppkt (iii) dyrektywy 75/442, zmienionej decyzja 96/350, należy interpretować $w$ ten sposób, ̇̇e w braku transpozycji do prawa państwa członkowskiego dyrektywy Rady 91/676/EWG z dnia 12 grudnia 1991 r. dotyczacej ochrony wód przed zanieczyszczeniami powodowanymi przez azotany pochodzenia rolniczego nie można uznać, iż odchody z hodowli wytworzone $w$ ramach hodowli trzody chlewnej usytuowanej $w$ tym państwie członkowskim sq $w$ zwiazku z obowiąywaniem tej dyrektywy „objęte inna legislacja” w rozumieniu wymienionego przepisu.

4) Przy założeniu, iż gnojowice wytworzona i przechowywana $w$ gospodarstwie hodowli trzody chlewnej należy zakwalifikować jako „odpady” $w$ rozumieniu art. 1 lit. a) akapit pierwszy dyrektywy 75/44, zmienionej decyzja 96/350:

- art. 8 tej dyrektywy należy interpretować $w$ ten sposób, $\dot{z}$ e bez względu na warunki nie dopuszcza on udzielenia rzeczonemu posiadaczowi zezwolenia na usuwanie tych odpadów poprzez ich sprzedaż rolnikowi wykorzystującemu je jako nawóz na swoich gruntach, jeżeli okaże się, że rolnik ten ani nie posiada zezwolenia, o którym mowa $w$ art. 10 wspomnianej dyrektywy, ani nie jest zwolniony z obowiąku posiadania takiego zezwolenia, ani zarejestrowany zgodnie z przepisami art. 11 tej dyrektywy; oraz 
- art. 8 w zwiąku z art. 10 i 11 wspomnianej dyrektywy należy interpretować $w$ ten sposób, że sprzeciwiaja się one temu, aby zbycie odpadów przez wspomnianego posiadacza na rzecz rolnika wykorzystujacego je jako nawóz na swoich gruntach i posiadającego zezwolenie wymienione $w$ rzeczonym art. 10 lub zwolnionego z obowiazku posiadania takiego zezwolenia $i$ zarejestrowanego zgodnie z rzeczonym art. 11 było poddane warunkowi ponoszenia przez tego posiadacza odpowiedzialności za przestrzeganie przez rolnika przepisów mających zastosowanie do czynności odzyskiwania wykonywanych przez tego rolnika na mocy prawa Unii dotyczacego gospodarki odpadami i nawozami.

\subsubsection{Wyrok Trybunału z dnia 7 listopada 2013 r. w sprawie C-23/13}

Komisja Europejska przeciwko Republice Francuskiej ${ }^{8}$

Przedmiot: uchybienie zobowiązaniom państwa członkowskiego; naruszenie art. 3 i 4 dyrektywy Rady 91/271/EWG z dnia 21 maja 1991 r. dotyczącej oczyszczania ścieków komunalnych (Dz.U. L 135, s. 40); uchybienia dotyczące zbierania i oczyszczania ścieków komunalnych z ośmiu aglomeracji.

Sentencja:

1) Nie zapewniajac

- zbierania ścieków komunalnych z aglomeracji Basse-Terre, o równoważnej liczbie mieszkańców ponad $15000 i$

- oczyszczania ścieków komunalnych z aglomeracji Ajaccio-Sanguinaires, Basse-Terre, Bastia-Nord, Cayenne-Leblond i Saint-Denis, o równoważnej liczbie mieszkańców ponad 15000, Republika Francuska uchybita zobowiązaniom cią̇̇acym na niej zgodnie z art. 3 i art. 4 ust. 1 i 3 dyrektywy Rady 91/271/EWG z dnia 21 maja 1991 r. dotyczącej oczyszczania ścieków komunalnych. 
2) Republika Francuska zostaje obciążona kosztami postępowania.

2.1.9. Wyrok Trybunału z dnia 12 grudnia 2013 r. w sprawie C-292/12 Ragn-Sells AS przeciwko Sillamäe Linnavalitsus ${ }^{9}$

(wniosek o wydanie orzeczenia w trybie prejudycjalnym złożony przez Tartu ringkonnakohus, Estonia)

Przedmiot: dyrektywa 2008/98/WE; gospodarka odpadami; artykuł 16 ust. 3; zasada bliskości; rozporządzenie (WE) nr 1013/2006; przemieszczanie odpadów; zmieszane odpady komunalne; odpady przemysłowe i odpady budowlane; procedura przyznawania koncesji na świadczenie usług w zakresie zbiórki i transportu odpadów wytworzonych na terenie gminy; ciążący na przyszłym koncesjonariuszu obowiązek przetransportowania zebranych odpadów do instalacji przetwarzania odpadów wskazanych przez organ udzielający koncesji; odpowiednie i najbliższe instalacje przetwarzania odpadów.

Sentencja:

1) Przepisy rozporzqdzenia (WE) $\mathrm{nr} 1013 / 2006$ Parlamentu Europejskiego i Rady z dnia 14 czerwca 2006 r. $w$ sprawie przemieszczania odpadów $w$ związku z art. 16 dyrektywy 2008/98/WE Parlamentu Europejskiego i Rady z dnia 19 listopada 2008 r. $w$ sprawie odpadów oraz uchylającej niektóre dyrektywy należy interpretować $w$ ten sposób, ̇̇e: - przepisy te zezwalaja jednostce samorządu lokalnego na nałożenie na przedsiębiorstwo prowadzące zbiórkę odpadów na jej terenie obowiązku transportowania zmieszanych odpadów komunalnych zebranych od gospodarstw domowych, a w stosownym wypadku także od innych wytwórców, do odpowiedniej i najblizszej instalacji przetwarzania, która zlokalizowana jest $w$ tym samym państwie członkowskim co wskazana jednostka samorządu lokalnego; 
- przepisy te nie zezwalaja jednostce samorzadu lokalnego na nałożenie na przedsiębiorstwo prowadzace zbiórkę odpadów na jej terenie obowiązku transportowania odpadów przemystowych i odpadów budowlanych wytworzonych na jej terenie do odpowiedniej i najbliższej instalacji przetwarzania, która zlokalizowana jest $w$ tym samym państwie członkowskim co wskazana jednostka samorządu lokalnego, $w$ sytuacji gdy odpady te sa przeznaczone do odzysku, jeżeli wytwórcy tych odpadów sq zobowiązani albo do przekazania ich temu przedsiębiorstwu, albo do dostarczenia ich bezpośrednio do rzeczonej instalacji.

2) Artykuty 49 TFUE i 56 TFUE nie maja zastosowania do sytuacji takiej jak analizowana $w$ postępowaniu głównym, w której wszystkie elementy ograniczają się do obrębu jednego państwa członkowskiego.

\subsubsection{Wyrok Trybunału z dnia 12 grudnia 2013 r. w sprawach} połączonych C-241/12 i C-242/12 Postępowania karne przeciwko Shell Nederland Verkoopmaatschappij BV (C-241/12) i Belgian Shell NV (C-242/12) ${ }^{10}$ (wnioski o wydanie orzeczenia w trybie prejudycjalnym złożone przez Rechtbank te Rotterdam, Niderlandy)

Przedmiot: środowisko naturalne; odpady; pojęcie; dyrektywa 2006/12/WE; przemieszczanie odpadów; informowanie właściwych władz krajowych; rozporządzenie (EWG) nr 259/93; występowanie działania polegającego na usuwaniu, zamiaru usunięcia lub zobowiązania do usunięcia substancji lub przedmiotu.

Sentencja:

Artykuł 2 lit. a) rozporządzenia Rady (EWG) nr 259/93 z dnia 1 lutego 1993 r. w sprawie nadzoru i kontroli przesyłania odpadów w obrębie, do Wspólnoty Europejskiej oraz poza jej obszar, zmienionego rozporządzeniem Komisji (WE) nr 2557/2001

10 http://curia.europa.eu 
z dnia 28 grudnia 2001 r. należy interpretować $w$ ten sposób, ̇̇e $w$ sytuacji takiej, jak sytuacja $w$ postępowaniu głównym nie jest objęta pojęciem odpadów $w$ rozumieniu tego przepisu partia oleju napędowego przypadkowo zmieszana z inna substancja, pod warunkiem że jej posiadacz rzeczywiście ma zamiar ponownego wprowadzenia do obrotu tej partii zmieszanej z innym produktem, czego stwierdzenie należy do sq̨du krajowego.

\subsection{OCENA ODDZIAŁYWANIA NA ŚRODOWISKO}

2.2.1. Wyrok Trybunału z dnia 14 marca 2013 r. w sprawie C-420/11 Jutta Leth przeciwko Republik Österreich i Land Niederösterreich ${ }^{11}$ (wniosek o wydanie orzeczenia w trybie prejudycjalnym złożony przez Oberster Gerichtshof, Austria)

Przedmiot: wykładnia art. 3 dyrektywy Rady 85/337/EWG z dnia 27 czerwca 1985 r. w sprawie oceny skutków wywieranych przez niektóre przedsięwzięcia publiczne i prywatne na środowisko naturalne (Dz.U. L 175, s. 40), zmienionej dyrektywą Rady 97/11/WE z dnia 3 marca 1997 r. (Dz.U. L 73, s. 5) oraz dyrektywą 2003/35/WE Parlamentu Europejskiego i Rady z dnia 26 maja 2003 r. (Dz.U. L 156, s. 17); zezwolenie na realizację przedsięwzięcia wydane bez przeprowadzenia właściwej oceny jego wpływu na środowisko; skarga jednostki mająca na celu zasądzenie odszkodowania za zmniejszenie wartości należącej do niej nieruchomości w wyniku realizacji wspomnianego przedsięwzięcia; cele oceny skutków wywieranych przez niektóre przedsięwzięcia publiczne i prywatne na środowisko naturalne; objęcie lub brak objęcia jednostek ochroną przed wystąpieniem szkód majątkowych.

Sentencja:

Artykut 3 dyrektywy Rady 85/337/EWG z dnia 27 czerwca 1985 r. w sprawie oceny skutków wywieranych przez niektóre przedsięwzięcia publiczne i prywatne na środowisko naturalne,

11 Dz.Urz. UE C 141 z 18.05.2013. 
zmienionej dyrektywa Rady 97/11/WE z dnia 3 marca 1997 r. i dyrektywa 2003/35/WE Parlamentu Europejskiego i Rady z dnia

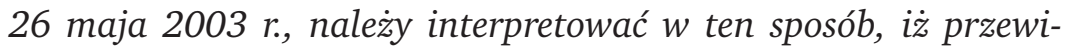
dziana $w$ tym przepisie ocena oddziaływania na środowisko nie obejmuje oceny oddziaływania danego przedsięwzięcia na wartość dóbr materialnych. Szkody majątkowe będące bezpośrednimi konsekwencjami oddziatywania przedsięwzięć publicznych lub prywatnych na środowisko sq jednak objęte realizowanym przez tę dyrektywe celem ochrony.

Okoliczność, iż przeprowadzenia oceny oddziaływania na środowisko zaniechano z naruszeniem wymogów wskazanej dyrektywy, co do zasady nie prowadzi sama $w$ sobie, $w$ świetle prawa Unii $i$ bez uszczerbku dla mniej restrykcyjnych norm prawa krajowego $w$ dziedzinie odpowiedzialności państwa, do powstania po stronie jednostki uprawnienia do naprawienia szkody czysto majątkowej wywołanej spadkiem wartości jej nieruchomości ze względu na spowodowane przez to przedsięwzięcie skutki dla środowiska. Zadaniem sadu krajowego jest jednak zbadanie, czy spetnione sa wymogi prawa Unii dotyczace powstania uprawnienia do odszkodowania, $w$ tym $w$ szczególności, czy istnieje bezpośredni związek przyczynowy między zarzucanym naruszeniem a poniesiona szkodą.

\subsubsection{Wyrok Trybunału z dnia 21 marca 2013 r. w sprawie C-244/12}

Salzburger Flughafen $\mathrm{GmbH}$ przeciwko Umweltsenat ${ }^{12}$

(wniosek o wydanie orzeczenia w trybie prejudycjalnym złożony przez Verwaltungsgerichtschof, Austria)

Przedmiot: wykładnia dyrektywy Rady 85/337/EWG z dnia 27 czerwca 1985 r. w sprawie oceny skutków wywieranych przez niektóre przedsięwzięcia publiczne i prywatne na środowisko naturalne (Dz.U. L 175, s. 40), zmienionej dyrektywą Rady 97/11/WE z dnia 3 marca 1997 r. (Dz.U. L 73, s. 5); przedsięwzięcia podlegające ocenie; rozbudowa portu lot-

12 Dz.Urz. UE C 156 z 01.06.2013. 
niczego; uregulowanie państwa członkowskiego przewidujące ocenę oddziaływania takiego przedsięwzięcia na środowisko wyłącznie w przypadku zwiększenia liczby lotów o co najmniej 20000 rocznie.

Sentencja:

1) Artykuł 2 ust. 1, a taki்e art. 4 ust. 2 lit. b) i art. 4 ust. 3 dyrektywy Rady 85/337/EWG z dnia 27 czerwca 1985 r. $w$ sprawie oceny skutków wywieranych przez niektóre przedsięwzięcia publiczne i prywatne na środowisko naturalne, zmienionej dyrektywa Rady 97/11/WE z dnia 3 marca 1997 r., stoja na przeszkodzie uregulowaniom krajowym, które poddaja przedsięwzięcia związane ze zmiana infrastruktury portu lotniczego i objęte załącznikiem II do tej dyrektywy ocenie oddziaływania na środowisko jedynie $w$ sytuacji, gdy przedsięwzięcia te moga doprowadzić do zwiększenia liczby operacji lotniczych o co najmniej 20000 rocznie.

2) W sytuacji gdy państwo członkowskie, na podstawie art. 4 ust. 2 lit. b) dyrektywy 85/337, zmienionej dyrektywa 97/11, odnoszącego się do przedsięwzięć objętych zatącznikiem II do tej dyrektywy, ustali próg taki jak ten, o którym mowa $w$ postępowaniu głównym, niezgodny ze zobowiązaniami określonymi $w$ art. 2 ust. 1 i $w$ art. 4 ust. 3 tej dyrektywy, przepisy art. 2 ust. 1, a takize art. 4 ust. 2 lit. a) i art. 4 ust. 3 tej dyrektywy wywieraja skutek bezpośredni, który oznacza, że właściwe władze krajowe musza zapewnić, aby zbadano najpierw, czy należy obawiać się, że dane przedsięwzięcia wywrq istotne skutki dla środowiska, a jeśli tak jest, to owe władze muszq zapewnić, aby skutki te zostaty następnie poddane ocenie. 
2.2.3. Wyrok Trybunału z dnia 18 kwietnia 2013 r. w sprawie C-463/11 $L$ przeciwko $M^{13}$ (wniosek o wydanie orzeczenia w trybie prejudycjalnym złożony przez Verwaltungsgerichtshof Baden-Württemberg, Niemcy)

Przedmiot: wykładnia art. 3 ust. 4 i 5 dyrektywy 2001/42/ /WE Parlamentu Europejskiego i Rady z dnia 27 czerwca 2001 r. w sprawie oceny wpływu niektórych planów i programów na środowisko (Dz.U. L 197, s. 30); zakres stosowania; ustawodawstwo krajowe przewidujące procedurę przyspieszoną, która nie obejmuje oceny wpływu na środowisko, dla uchwalania planów zagospodarowania dotyczących małych obszarów na poziomie lokalnym, spełniających określone kryteria jakościowe i ilościowe; nieprawidłowa ocena kryteriów jakościowych.

Sentencja:

Artykut 3 ust. 5 w związku z art. 3 ust. 4 dyrektywy 2001/42/ WE Parlamentu Europejskiego i Rady z dnia 27 czerwca 2001 r. $w$ sprawie oceny wpływu niektórych planów i programów na środowisko należy interpretować $w$ ten sposób, że stoi on na przeszkodzie uregulowaniu krajowemu takiemu jak będace przedmiotem postępowania głównego, zgodnie z którym naruszenie warunku jakościowego, wprowadzonego przepisem transponującym tę dyrektywę $w$ celu zwolnienia szczególnego rodzaju planu zagospodarowania z oceny środowiskowej na podstawie owej dyrektywy, nie ma wpływu na ważność tego planu.

13 Dz.Urz. UE C 164 z 08.06.2013. 


\subsection{PARTYCYPACJA SPOŁECZEŃSTWA W OCHRONIE ŚRODOWISKA}

\subsubsection{Wyrok Trybunału (wielka izba) z dnia 15 stycznia 2013 r.} w sprawie C-416/10 Jozef Križan i in. przeciwko Slovenská inšpekcia životného prostredia ${ }^{14}$ (wniosek o wydanie orzeczenia w trybie prejudycjalnym złożony przez Najvyšší súd Slovenskej republiky, Słowacja)

Przedmiot: wykładnia art. 191 ust. 1 i 2 oraz art. 267 TFUE, dyrektywy Rady 96/61/WE z dnia 24 września 1996 r. dotyczącej zintegrowanego zapobiegania zanieczyszczeniom i ich kontroli (Dz.U. L 257, s. 26), a w szczególności jej art. 1, 6, 15 i 15a, dyrektywy Rady 85/337/EWG z dnia 27 czerwca 1985 r. w sprawie oceny skutków wywieranych przez niektóre przedsięwzięcia publiczne i prywatne na środowisko naturalne (Dz.U. L 175, s. 40), a w szczególności jej art. 2 i 10a, a także art. 6 i 9 Konwencji (z Aarhus) o dostępie do informacji, udziale społeczeństwa $\mathrm{w}$ podejmowaniu decyzji oraz dostępie do sprawiedliwości w sprawach dotyczących środowiska, zawartej w imieniu Wspólnoty Europejskiej decyzją Rady z dnia 17 lutego 2005 r. (Dz.U. L 124, s. 1); budowa składowiska; ocena oddziaływania tego przedsięwzięcia na środowisko; udział społeczeństwa w procesach decyzyjnych; możliwość zwrócenia się przez sąd państwa członkowskiego do Trybunału Sprawiedliwości z pytaniem prejudycjalnym dotyczącym zastosowania z urzędu prawa Unii z dziedziny ochrony środowiska, w sytuacji gdy trybunał konstytucyjny tego państwa wykluczył takie zastosowanie w orzeczeniu, które dla sądu odsyłającego jest wiążące

Sentencja:

1) Artykut 267 TFUE należy interpretować $w$ ten sposób, że sąd krajowy ma obowiazzek skierować z urzędu do Trybunału Sprawiedliwości Unii Europejskiej wniosek o wydanie orzeczenia $w$ trybie prejudycjalnym, choć orzeka $w$ następstwie odestania po uchyleniu jego pierwszego 
orzeczenia $w$ drodze kasacji przez trybunat konstytucyjny danego państwa członkowskiego, a przepis krajowy nakazuje mu rozstrzygnać spór zgodnie z opinią prawną wyrażona przez ów trybunat.

2) Dyrektywa Rady 96/61/WE z dnia 24 września 1996 r. dotyczaca zintegrowanego zapobiegania zanieczyszczeniom $i$ ich kontroli, zmieniona rozporzadzeniem (WE) nr 166/2006 Parlamentu Europejskiego i Rady z dnia 18 stycznia $2006 r$. powinna być interpretowana $w$ ten sposób, $\dot{z} e$ :

- wymaga, aby zainteresowana społeczność miała dostęp do decyzji z zakresu planowania przestrzennego, takiej jak decyzja sporna $w$ postępowaniu głównym, od początku danego postępowania $w$ sprawie zezwolenia na przedsięwzięcie;

- nie pozwala organom krajowym odmówić zainteresowanej społeczności dostępu do takiej decyzji w oparciu o ochronę poufności informacji handlowych lub przemystowych przewidziana $w$ prawie krajowym lub prawie Unii $w$ celu ochrony prawnie uzasadnionego interesu gospodarczego oraz

- nie stoi na przeszkodzie temu, aby nieuzasadniona odmowa udostępnienia zainteresowanej społeczności decyzji z zakresu planowania przestrzennego, takiej jak decyzja sporna $w$ postępowaniu głównym, podczas postępowania administracyjnego pierwszej instancji mogła zostać konwalidowana podczas postępowania drugiej instancji, pod warunkiem że wszystkie możliwości sa jeszcze dostępne $i \dot{z}$ e konwalidacja na tym etapie postępowania umożliwia jeszcze zainteresowanej spoŁeczności rzeczywisty wpływ na wynik procesu decyzyjnego, czego zbadanie należy do sądu krajowego.

3) Artykut 15a dyrektywy 96/61 w brzmieniu zmienionym rozporzadzeniem $n r$ 166/2006 należy interpretować $w$ ten sposób, ̇̇e członkowie zainteresowanej społeczności powinni mieć możliwość, $w$ ramach środka zaskarżenia przewidzianego $w$ tym postanowieniu, wniesienia do sądu lub innego niezależnego i bezstronnego organu usta- 
nowionego przez właściwe prawo o zarządzenie środków tymczasowych zawieszających czasowo obowiazywanie pozwolenia $w$ rozumieniu art. 4 tej dyrektywy $w$ oczekiwaniu na wydanie ostatecznej decyzji.

4) Orzeczenie sądu krajowego wydane w ramach postępowania krajowego realizujacego obowiązi wynikające z art. 15 a dyrektywy 96/61 w brzmieniu zmienionym rozporządzeniem nr 166/2006 oraz art. 9 ust. 2 i 4 Konwencji o dostępie do informacji, udziale społeczeństwa $w$ podejmowaniu decyzji oraz dostępie do wymiaru sprawiedliwości $w$ sprawach dotyczacych środowiska podpisanej $w$ Aarhus $w$ dniu 25 czerwca 1998 r. i przyjętej $w$ imieniu Wspólnoty Europejskiej decyzją Rady 2005/370/WE z dnia 17 lutego 2005 r., które stwierdza nieważność pozwolenia udzielonego z naruszeniem przepisów owej dyrektywy, nie może jako takie stanowić nieuzasadnionego naruszenia prawa własności przysługującego prowadzacemu przedsięwzięcie, zagwarantowanego $w$ art. 17 Karty praw podstawowych Unii Europejskiej.

\subsubsection{Wyrok Trybunału z dnia 11 kwietnia 2013 r. w sprawie C-260/11}

The Queen na wniosek Davida Edwardsa, Lilian Pallikaropoulos przeciwko

Environment Agency, First Secretary of State, Secretary of State for Environment, Food and Rural Affairs ${ }^{15}$

(wniosek o wydanie orzeczenia w trybie prejudycjalnym złożony przez Supreme Court of the United Kingdom, Zjednoczone Królestwo)

Przedmiot: wykładnia art. 10a dyrektywy Rady 85/337/ EWG z dnia 27 czerwca 1985 r. w sprawie oceny skutków wywieranych przez niektóre przedsięwzięcia publiczne i prywatne na środowisko naturalne (Dz.U. L 175, s. 40), zmienionej dyrektywą 2003/35/WE Parlamentu Europejskiego i Rady z dnia 26 maja 2003 r. przewidującą udział społeczeństwa w odniesieniu do sporządzania niektórych planów i programów w zakresie śro- 
dowiska oraz zmieniającą w odniesieniu do udziału społeczeństwa i dostępu do wymiaru sprawiedliwości dyrektywy Rady 85/337/EWG i 96/61/WE; deklaracja Komisji (Dz.U. L 156, s. 17); wykładnia art. 15a dyrektywy Rady 96/61/WE z dnia 24 września 1996 r. dotyczącej zintegrowanego zapobiegania zanieczyszczeniom i ich kontroli (Dz.U. L 257, s. 26), zmienionej dyrektywą 2003/35/WE; wykładnia art. 9 ust. 4 konwencji (z Aarhus) o dostępie do informacji, udziale społeczeństwa w podejmowaniu decyzji oraz dostępie do [wymiaru] sprawiedliwości w sprawach dotyczących środowiska zatwierdzonej w imieniu Wspólnoty Europejskiej decyzją Rady 2005/370/WE z dnia 17 lutego 2005 r. (Dz.U. L 124, s. 1); obciążenie strony przegrywającej kosztami postępowania; pojęcie „niedyskryminacyjnego ze względu na koszty” charakteru postępowań sądowych.

Sentencja:

$Z$ wymogu ustanowionego $w$ art. 10a akapit piaty dyrektywy Rady 85/337/EWG z dnia 27 czerwca 1985 r. w sprawie oceny skutków wywieranych przez niektóre przedsięwzięcia publiczne i prywatne na środowisko naturalne oraz $w$ art. 15a akapit piaty dyrektywy Rady 96/61/WE z dnia 24 września 1996 r. dotyczacej zintegrowanego zapobiegania zanieczyszczeniom $i$ ich kontroli, zmienionych dyrektywa 2003/35/WE Parlamentu Europejskiego i Rady z dnia 26 maja 2003 r., zgodnie z którym to wymogiem postępowanie nie może mieć dyskryminacyjnego ze względu na koszty charakteru, wynika, i̇̇ nie można uniemożliwiać objętym tym wymogiem osobom wszczynania lub kontynuowania postępowania z wchodzacej $w$ zakres stosowania tych przepisów skargi ze względu na mogace wynikać z tego faktu obcią̇enie finansowe. $W$ sytuacji gdy sąd krajowy ma wydać rozstrzygnięcie $w$ przedmiocie obciązenia kosztami jednostki, której żądania jako strony skarżacej $w$ sporze $w$ dziedzinie ochrony środowiska nie zostały uwzględnione, lub, bardziej ogólnie rzecz ujmując, ma zajać, jak może to mieć miejsce $w$ przypadku sądów brytyjskich, na poprzedzającym postępowanie etapie, stanowisko $w$ przedmiocie ewentualnego ograniczenia kosztów, jakimi może zostać obciążona strona, której żądania nie zostana uwzględnione, winien on zapewnić, $\dot{z}$ e wymóg ten jest przestrzegany, uwzględniając zarówno interes 
tej chcacej bronić swych praw osoby, jak i związany z ochrona środowiska interes ogólny.

W ramach tej oceny sąd krajowy nie może przeprowadzać analizy, odnoszac się jedynie do sytuacji ekonomicznej tego zainteresowanego, lecz winien ją również oprzeć na obiektywnej analizie kwoty kosztów. Winien on ponadto uwzględnić sytuację stron postępowania, racjonalne szanse wygrania sprawy przez powoda, znaczenie, jakie sprawa ma dla niego oraz dla ochrony środowiska, złożoność przepisów materialnych i proceduralnych majacych zastosowanie $w$ sprawie, jak również potencjalna pochopność skargi na poszczególnych etapach postępowania, a także to, czy prawo krajowe przewiduje system pomocy prawnej lub system ograniczania odpowiedzialności z tytułu kosztów postępowania.

Natomiast okoliczność polegająca na tym, że zainteresowany nie zostat powstrzymany przed dochodzeniem $w$ praktyce swych $\dot{z} a q d a n ́$, nie wystarcza sama $w$ sobie do uznania, $i \dot{z}$ dane postępowanie nie ma w jego przypadku dyskryminacyjnego ze względu na koszty charakteru.

Wreszcie ocena ta nie może być przeprowadzana wedtug odmiennych kryteriów $w$ zależności od tego, czy dokonuje jej sąd po przeprowadzeniu postępowania $w$ pierwszej instancji, czy też na

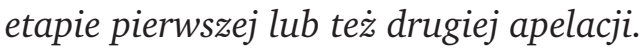

\subsubsection{Wyrok Trybunału z dnia 18 lipca 2013 r. w sprawie C-515/11 Deutsche Umwelthilfe eV przeciwko Bundesrepublik Deutschland ${ }^{16}$ (wniosek o wydanie orzeczenia w trybie prejudycjalnym złożony przez Verwaltungsgericht Berlin, Niemcy)}

Przedmiot: wykładnia art. 2 pkt 2 dyrektywy 2003/4/WE Parlamentu Europejskiego i Rady z dnia 28 stycznia 2003 r. w sprawie publicznego dostępu do informacji dotyczących środowiska i uchylającej dyrektywę Rady 90/313/EWG (Dz.U. L 41, s. 26); obowiązek udostępnienia każdemu wnioskodawcy przez władze publiczne posiadanych przez nie informacji do- 
tyczących środowiska; przepisy krajowe zwalniające najwyższe władze federalne z obowiązku udzielenia informacji w zakresie, w jakim uczestniczą one w procesie ustawodawczym; ograniczenie uprawnienia państw członkowskich do wyłączenia z zakresu przewidzianego w dyrektywie 2003/4/WE pojęcia „organów władzy publicznej” organów pełniących funkcje o charakterze ustawodawczym

Sentencja:

Artykut 2 pkt 2 zdanie drugie dyrektywy 2003/4/WE Parlamentu Europejskiego i Rady z dnia 28 stycznia 2003 r. w sprawie publicznego dostępu do informacji dotyczacych środowiska i uchylajacej dyrektywę Rady 90/313/EWG należy interpretować $w$ ten sposób, ̇̇e przyznana $w$ tym przepisie państwom członkowskim możliwość, by nie traktować jako organów wtadzy publicznej majacych obowiązek przyznania dostępu do posiadanych informacji o środowisku „organów lub instytucji petniących funkcje o charakterze [...] ustawodawczym" nie może dotyczyć ministerstw $w$ zakresie, $w$ jakim opracowuja i wydaja przepisy normatywne o randze nï̇szej niż ustawowa.

\subsubsection{Wyrok Trybunału z dnia 7 listopada 2013 r. w sprawie C-72/12 Gemeinde Altrip i inni przeciwko Land Rheinland-Pfalz ${ }^{17}$ (wniosek o wydanie orzeczenia w trybie prejudycjalnym złożony przez Bundesverwaltungsgericht, Niemcy)}

Przedmiot: dyrektywa 85/337/EWG; ocena skutków wywieranych na środowisko naturalne; konwencja z Aarhus; dyrektywa 2003/35/WE; prawo do wniesienia skargi na decyzję o wydaniu zezwolenia; stosowanie w czasie; postępowanie w sprawie zatwierdzenia planu wszczęte przed dniem upływu terminu na dokonanie transpozycji dyrektywy 2003/35/WE; decyzja wydana po tej dacie; przesłanki dopuszczalności skargi; naruszenie prawa; charakter uchybienia proceduralnego, na który można się powołać; zakres kontroli.

17 http://curia.europa.eu 
Sentencja:

1) $Z$ uwagi na to, że dyrektywa 2003/35/WE Parlamentu Europejskiego i Rady z dnia 26 maja 2003 r. przewidująca udział społeczeństwa $w$ odniesieniu do sporządzania niektórych planów i programów $w$ zakresie środowiska oraz zmieniajaca $w$ odniesieniu do udziału społeczeństwa i dostępu do wymiaru sprawiedliwości dyrektywy Rady 85/337/EWG i 96/61/WE, którq dodano art. 10a do dyrektywy Rady 85/337/EWG z dnia 27 czerwca 1985 r. $w$ sprawie oceny skutków wywieranych przez niektóre przedsięwzięcia publiczne i prywatne na środowisko naturalne, stanowi, iz powinna być transponowana najpóźniej do dnia 25 czerwca 2005 r., powinna ona być interpretowana $w$ ten sposób, $i \dot{z}$ przepisy prawa krajowego przyjęte $w$ celu transpozycji tego artykułu powinny mieć zastosowanie również do administracyjnych postępowań $w$ sprawie wydania zezwolenia wszczętych przed dniem 25 czerwca 2005 r., jeżeli $w$ ich ramach zezwolenia zostaty wydane po tym dniu.

2) Artykut 10a dyrektywy 85/337, zmienionej dyrektywa 2003/35, należy interpretować $w$ ten sposób, iz stoi on na przeszkodzie temu, by państwa członkowskie ograniczaty stosowanie przepisów transponujących ten artykut wyłącznie do wypadku, w którym zgodność decyzji z prawem jest kwestionowana z tego względu, że ocena skutków wywieranych na środowisko naturalne nie została przeprowadzona, bez rozszerzenia go na przypadek, $w$ którym taka ocena została przeprowadzona, lecz jest nieprawidtowa.

3) Artykut 10a, lit. b) dyrektywy 85/337, zmienionej dyrektywą 2003/35, należy interpretować $w$ ten sposób, że nie stoi on na przeszkodzie krajowemu orzecznictwu, które nie uznaje naruszenia prawa $w$ rozumieniu tego artykułu, jeżeli wykazano, iz $w$ świetle okoliczności danej sprawy można oczekiwać, że bez uchybienia proceduralnego, na które powołał się wnoszacy środek prawny, zaskarżona decyzja nie miałaby odmiennej treści. Jest to jednak możliwe tylko pod warunkiem, że sqad lub organ, 
przed którymi toczy sie postępowanie, nie nakładają na wnoszacego środek prawny w jakikolwiek sposób ciężaru dowodu $w$ tym zakresie i orzekaja $w$ stosownym wypad$k u$ w świetle dowodów przedstawionych przez inwestora lub właściwe władze i bardziej ogólnie $w$ świetle całości akt sprawy, które im przedtożono, uwzględniając między innymi stopień wagi podnoszonego uchybienia i badajacc $w$ szczególności $w$ tym kontekście, czy pozbawiło ono zainteresowana społeczność jednej z gwarancji wprowadzonych, aby umożliwiać tej społeczności, zgodnie z celami dyrektywy 85/337, dostęp do informacji i uprawnienie do uczestniczenia $w$ procesie podejmowania decyzji.

\subsubsection{Wyrok Trybunału (wielka izba) z dnia 19 grudnia 2013 r.} w sprawie C-279/12 Fish Legal i Emily Shirley przeciwko Information

Commissioner inni $^{18}$ (wniosek o wydanie orzeczenia w trybie prejudycjalnym: Upper Tribunal-Administrative Appeals Chamber, Zjednoczone Królestwo)

Przedmiot: konwencja z Aarhus; dyrektywa 2003/4/WE; publiczny dostęp do informacji o środowisku; zakres stosowania; pojęcie „organu władzy publicznej”, przedsiębiorstwa kanalizacyjne i wodociągowe; prywatyzacja sektora gospodarki wodnej w Anglii i Walii.

Sentencja:

1) Aby ustalić, czy można zakwalifikować podmioty takie jak United Utilities Water plc, Yorkshire Water Services Ltd $i$ Southern Water Services Ltd jako osoby prawne sprawujace na mocy prawa krajowego publiczne funkcje administracyjne $w$ rozumieniu art. 2 ust. 2 lit. b) dyrektywy 2003/4/WE Parlamentu Europejskiego i Rady z dnia 28 stycznia 2003 r. $w$ sprawie publicznego dostępu do informacji dotyczacych środowiska i uchylającej dyrektywe Rady 90/313/EWG, należy sprawdzić, czy na podstawie

18 http://curia.europa.eu 
mających do nich zastosowanie przepisów prawa krajowego przyznano im uprawnienia wychodzace poza zakres norm mających zastosowanie $w$ stosunkach między podmiotami prawa prywatnego.

2) Przedsiębiorstwa takie jak United Utilities Water plc, Yorkshire Water Services Ltd i Southern Water Services Ltd, które świadcza publiczne ustugi dotyczace środowiska, podlegają organowi lub osobie, o których mowa $w$ art. 2 ust. 2 lit. a) lub b) dyrektywy 2003/4, efektem czego należy je uznać na podstawie art. 2 ust. 2 lit. c) tej dyrektywy za „organy władzy publicznej”, jeżeli przedsiębiorstwa te nie określają naprawdę niezależnie sposobu, $w$ jaki świadcza te ustugi, gdyż organ władzy publicznej objęty zakresem stosowania art. 2 ust. 2 lit. a) lub b) tej dyrektywy ma możliwość wywierania decydującego wptywu na działania tych przedsiębiorstw $w$ dziedzinie ochrony środowiska.

3) Artykut 2 ust. 2 lit. b) dyrektywy 2003/4 należy interpretować $w$ ten sposób, $i \dot{z}$ osoba objęta zakresem stosowania tego przepisu jest organem władzy publicznej $w$ zakresie wszystkich posiadanych przez nia informacji o środowisku. Prowadzace komercyjna działalność spótki takie jak United Utilities Water plc, Yorkshire Water Services Ltd i Southern Water Services Ltd, które moga stanowić organ władzy publicznej na podstawie art. 2 ust. 2 lit. c) tej dyrektywy tylko wówczas, gdy przy świadczeniu usług publicznych $w$ dziedzinie ochrony środowiska podlegaja organowi lub osobie, o których mowa $w$ art. 2 ust. 2 lit. a) lub b) tej dyrektywy, nie mają obowiazku dostarczania informacji o środowisku, jeśli jest oczywiste, że informacje te pozostają bez związku ze świadczeniem takich ustug. 


\subsection{OCHRONA PRZYRODY}

\subsubsection{Wyrok Trybunału z dnia 7 lutego 2013 r. w sprawie C-517/11 Komisja Europejska przeciwko Republice Greckiej ${ }^{19}$}

Przedmiot: uchybienie zobowiązaniom państwa członkowskiego; naruszenie art. 6 ust. 2 dyrektywy Rady 92/43/EWG z dnia 21 maja 1992 r. w sprawie ochrony siedlisk przyrodniczych oraz dzikiej fauny i flory (Dz.U. L 206, s. 7); naruszenie art. 3 oraz art. 4 ust. 1 i 3 dyrektywy Rady 91/271/EWG z dnia 21 maja 1991 r. dotyczącej oczyszczania ścieków komunalnych (Dz.U. L 135, s. 40); nieprzyjęcie środków koniecznych do uniknięcia pogorszenia stanu jeziora Koroneia (prefektura Salonik) i jego zanieczyszczenia; niewprowadzenie systemu zbierania i oczyszczania ścieków komunalnych dla aglomeracji Langadas.

Sentencja:

1) Nie przyjmując środków koniecznych do uniknięcia pogorszenia stanu siedlisk przyrodniczych i siedlisk gatunków, dla których został sklasyfikowany specjalny obszar ochrony GR 1220009, i nie wprowadzając systemu zbierania i oczyszczania ścieków komunalnych dla aglomeracji Langadas, Republika Grecka uchybiła, odpowiednio, zobowiązaniom, które ciąża na niej na podstawie art. 6 ust. 2 dyrektywy Rady 92/43/EWG z dnia 21 maja $1992 r . w$ sprawie ochrony siedlisk przyrodniczych oraz dzikiej fauny i flory $w$ związku z art. 7 tej dyrektywy, jak równiė̇ zobowiązaniom, które cią̇̇ą na niej na podstawie art. 3 oraz art. 4 ust. 1 i 3 dyrektywy Rady 91/271/EWG z dnia 21 maja 1991 r. dotyczącej oczyszczania ścieków komunalnych.

2) Republika Grecka zostaje obciązona kosztami postępowania. 


\subsubsection{Wyrok Trybunału z dnia 11 kwietnia 2013 r. w sprawie C-258/11 Peter Sweetman i in. przeciwko An Bord Pleanala ${ }^{20}$ \\ (wniosek o wydanie orzeczenia w trybie prejudycjalnym złożony przez Supreme Court, Irlandia)}

Przedmiot: wykładnia art. 6 ust. 3 i 4 dyrektywy Rady 92/43/EWG z dnia 21 maja 1992 r. w sprawie ochrony siedlisk przyrodniczych oraz dzikiej fauny i flory (Dz.U. L 206, s. 7); ocena wpływu planu lub przedsięwzięcia na chroniony obszar; kryteria, jakie należy zastosować przy ocenie prawdopodobieństwa, że taki plan lub przedsięwzięcie może niekorzystnie wpłynąć na integralność danego terenu; konsekwencje zastosowania zasady ostrożności; budowa drogi przebiegającej przez obszar kandydujący do uzyskania statusu specjalnego obszaru ochrony.

Sentencja:

Artykut 6 ust. 3 dyrektywy Rady 92/43/EWG z dnia 21 maja 1992 r. $w$ sprawie ochrony siedlisk przyrodniczych oraz dzikiej fauny i flory należy interpretować $w$ ten sposób, że plan lub przedsięwzięcie bezpośrednio niezwiązane z zagospodarowaniem terenu ani niekonieczne do jego zagospodarowania naruszaja integralność tego terenu, jeżeli moga one uniemożliwić trwałe utrzymanie istotnych cech danego terenu, zwiazanych z występowaniem siedliska przyrodniczego o znaczeniu priorytetowym, którego ochrona uzasadniła umieszczenie tego terenu $w$ wykazie terenów mających znaczenie dla Wspólnoty $w$ rozumieniu tej dyrektywy. Przy dokonywaniu takiej oceny należy stosować zasadę ostrożności.

\subsection{OCHRONA KLIMATU}

\subsubsection{Wyrok Sądu z dnia 7 marca 2013 r. w sprawie T-370/11 Polska przeciwko Komisji ${ }^{21}$}

Przedmiot: żądanie stwierdzenia nieważności decyzji Komisji 2011/278/UE z dnia 27 kwietnia 2011 r. w sprawie usta-

20 Dz.Urz. UE C 156 z 01.06.2013.

21 Dz.Urz. UE C 114 z 20.04.2013. 
nowienia przejściowych zasad dotyczących zharmonizowanego przydziału bezpłatnych uprawnień do emisji w całej Unii na mocy art. 10a dyrektywy 2003/87/WE Parlamentu Europejskiego i Rady (Dz.U. L 130, s. 1).

Sentencja:

1) Skarga zostaje oddalona.

2) Rzeczpospolita Polska zostaje obcią̇ona kosztami postępowania.

2.5.2. Wyrok Trybunału z dnia 17 października 2013 r. w sprawie C-203/12 Billerud Karlsborg AB, Billerud Skärblacka $A B$ przeciwko Naturvårdsverket ${ }^{22}$ (wniosek o wydanie orzeczenia w trybie prejudycjalnym złożony przez Högsta domstolen, Szwecja)

Przedmiot: wykładnia art. 16 ust. 3 i 4 dyrektywy 2003/87/ /WE Parlamentu Europejskiego i Rady z dnia 13 października 2003 r. ustanawiającej system handlu przydziałami emisji gazów cieplarnianych we Wspólnocie oraz zmieniającej dyrektywę Rady 96/61/WE (Dz.U. L 275, s. 32); kary przewidziane w dyrektywie; obowiązek zapłaty kary przez operatora, który nie zwrócił do dnia 30 kwietnia roku kalendarzowego przydziałów w ilości odpowiadającej jego emisji, nawet jeżeli wynika to z zaniedbania, błędu administracyjnego lub problemów technicznych; ewentualna możliwość zwrotu lub obniżenia wysokości kary.

Sentencja:

1) Artykuł 16 ust. 3 i 4 dyrektywy 2003/87/WE Parlamentu Europejskiego i Rady z dnia 13 października 2003 r. ustanawiającej system handlu przydziałami emisji gazów cieplarnianych we Wspólnocie oraz zmieniajacej dyrektywę Rady 96/61/WE należy interpretować $w$ ten sposób, że nie dopuszcza on, by operator, który nie dokonat do dnia 30 kwietnia zwrotu uprawnień do emisji dwutlenku węgla odpowiadajacych jego emisji z roku poprzedniego, unikną przewidzianej $w$ tym przepisie kary finansowej

22 Dz.Urz. UE C 367 z 14.12.2013. 
z tytułu przekroczenia emisji, nawet jeżeli w tym dniu posiadał wystarczajacca ilość uprawnień.

2) Artykut 16 ust. 3 i 4 dyrektywy 2003/87 należy interpretować $w$ ten sposób, że wysokość ryczałtowej kary pienięznej przewidzianej $w$ tych przepisach nie może ulegać modyfikacji przez sad krajowy na podstawie zasady proporcjonalności.

\subsubsection{Wyrok Trybunału z dnia 17 października 2013 r. w sprawach} połączonych C-566/11, C-567/11, C-580/11, C-591/11, C-620/11 i C-640/11 Iberdrola, SA, Gas Natural SDG SA (C-566/11), Gas Natural SDG SA (C-567/11), Tarragona Power SL (C-580/11), Gas Natural SDG SA, Bizcaia Energía SL (C-591/11), Bahía de Bizcaia Electricidad SL (C-620/11), E.0N Generación SL $i$ in. (C-640/11) ${ }^{23}$ (wniosek o wydanie orzeczenia w trybie prejudycjalnym złożony przez Tribunal Supremo, Hiszpania)

Przedmiot: wykładnia art. 10 dyrektywy 2003/87/WE Parlamentu Europejskiego i Rady z dnia 13 października 2003 r. ustanawiającej system handlu przydziałami emisji gazów cieplarnianych we Wspólnocie oraz zmieniającej dyrektywę Rady 96/61/WE (Dz.U. L 275, s. 32); ochrona warstwy ozonowej; system handlu uprawnieniami do emisji gazów cieplarnianych we Wspólnocie; metoda przydziału uprawnień; bezpłatny przydział uprawnień.

Sentencja:

Artykul 10 dyrektywy 2003/87/WE Parlamentu Europejskiego i Rady z dnia 13 października 2003 r. ustanawiającej system handlu przydziałami emisji gazów cieplarnianych we Wspólnocie oraz zmieniającej dyrektywę Rady 96/61/WE, należy interpretować $w$ ten sposób, że nie sprzeciwia się on stosowaniu krajowych przepisów, takich jak rozpatrywane $w$ postępowaniach głównych, których celem i skutkiem jest obniżanie wynagrodzenia za działalność związana z produkcją energii elektrycznej o kwotę, o która

23 Dz.Urz. C 367 z 14.12.2013. 
wynagrodzenie to podwyższyło się $w$ zwiąku z wliczeniem wartości bezpłatnie przydzielonych uprawnień do cen ofert sprzedaży na hurtowym rynku energii elektrycznej.

\subsection{OCHRONA WÓD}

2.6.1. Wyrok Trybunału (wielka izba) z dnia 11 wrzeónia 2012 r. w sprawie C-43/10 Nomarchiaki Aftodioikisi Aitoloakarnanias i in. przeciwko Ypourgos Perivallontos i in. ${ }^{24}$ (wniosek o wydanie orzeczenia w trybie prejudycjalnym złożony przez Symvoulio tis Epikrateias,

\section{Grecja)}

Przedmiot: wykładnia dyrektywy 2000/60/WE Parlamentu Europejskiego i Rady z dnia 23 października 2000 r. ustanawiającej ramy wspólnotowego działania w dziedzinie polityki wodnej (Dz.U. L 327, s. 1); roboty mające na celu przekierowanie biegu rzeki; pojęcie terminu dla ustanowienia planów gospodarowania wodami dla obszarów dorzeczy w rozumieniu art. 13 ust. 6 dyrektywy.

Sentencja:

1) Wykładni art. 13 ust. 6 iart. 24 ust. 1 dyrektywy 2000/60/ /WE Parlamentu Europejskiego i Rady z dnia 23 października 2000 r. ustanawiającej ramy wspólnotowego działania $w$ dziedzinie polityki wodnej należy dokonywać $w$ ten sposób, ̇̇e wyznaczają one odpowiednio dzień 22 grudnia 2009 r. jako datę upływu terminu udzielonego państwom członkowskim na opublikowanie planów gospodarowania wodami $w$ dorzeczach $i$ dzień 22 grudnia 2003 r. jako najpóźniejszq datę upływu terminu na transpozycję przez państwa członkowskie tej dyrektywy, w szczególności jej art. 3-6, 9, 13 i 15.

2) Wykładni dyrektywy 2000/60 należy dokonywać $w$ ten sposób, że: 
- nie stoi ona zasadniczo na przeszkodzie przepisowi krajowemu, który zezwala, przed dniem 22 grudnia 2009 r., na transfer wody z jednego dorzecza do innego lub z jednego obszaru dorzecza do innego bez uprzedniego przyjęcia przez właściwe organy krajowe planów gospodarowania wodami dla odnośnych obszarów dorzeczy;

- taki transfer nie może poważnie zagrażać osiagnięciu celów wyznaczonych przez tę dyrektywę;

- niemniej jednak wspomniany transfer $w$ zakresie, $w$ jakim może powodować niekorzystne dla wody skutki takie jak wymienione $w$ art. 4 ust. 7 tej dyrektywy, może zostać zatwierdzony, przynajmniej jeśli spetnione sa przesłanki, o których mowa $w$ lit. a)-d) tego przepisu; oraz

- niemożność zaspokojenia przez zasoby wodne zawarte $w$ docelowym dorzeczu lub obszarze dorzecza jego zapotrzebowania na wodę pitna, do produkcji energii lub do nawadniania nie stanowi warunku koniecznego, aby taki transfer wody byt zgodny z ta dyrektywą, o ile spetnione sq wymienione wcześniej przestanki.

3) Zatwierdzenie przez parlament krajowy planów gospodarowania wodami $w$ dorzeczach, takich jak plany sporne $w$ postępowaniu przed sqdem krajowym, bez przeprowadzenia procedur informowania, konsultacji $i$ udziału społeczeństwa, nie wchodzi $w$ zakres stosowania art. 14 dyrektywy 2000/60, a w szczególności art. 14 ust. 1.

4) Wykładni dyrektywy Rady 85/337/EWG z dnia 27 czerwca 1985 r. $w$ sprawie oceny skutków wywieranych przez niektóre przedsięwzięcia publiczne i prywatne na środowisko naturalne, zmienionej dyrektywa 2003/35/WE Parlamentu Europejskiego i Rady z dnia 26 maja 2003 r., a w szczególności art. 1 ust. 5 tej dyrektywy, należy dokonywać $w$ ten sposób, że nie sprzeciwia się ona ustawie takiej jak ustawa 3481/2006 przyjęta przez parlament grecki $w$ dniu 2 sierpnia 2006 r., która zatwierdziła projekt częściowego przekierowania wód rzeki taki jak projekt sporny $w$ postępowaniu przed sq̨dem krajowym $w$ oparciu 
o ocene oddziaływania na środowisko dla tego projektu stanowiąca podstawę decyzji administracyjnej wydanej po przeprowadzeniu postępowania zgodnego z przewidzianymi $w$ tej dyrektywie obowiazkami poinformowania i udziału społeczeństwa, pomimo że $w$ postępowaniu sqdowym stwierdzona została nieważność tej decyzji, o ile ustawa ta stanowi szczególny akt ustawodawczy, tak $i \dot{z}$ cele tej dyrektywy moga być osiagnięte $w$ procesie ustawodawczym. Do sądu krajowego należy zbadanie, czy obie te przestanki zostaty spetnione.

5) Projekt częściowego przekierowania wód rzeki taki jak projekt sporny $w$ postępowaniu przed sądem krajowym nie powinien być uznany za plan lub program wchodzacy $w$ zakres stosowania dyrektywy 2001/42/WE Parlamentu Europejskiego i Rady z dnia 27 czerwca 2001 r. $w$ sprawie oceny wpływu niektórych planów i programów na środowisko.

6) Obszary wymienione $w$ krajowym wykazie terenów majacych znaczenie dla Wspólnoty przekazanym Komisji na podstawie art. 4 ust. 1 akapit drugi dyrektywy Rady 92/43/EWG z dnia 21 maja 1992 r. w sprawie ochrony siedlisk przyrodniczych oraz dzikiej fauny i flory $i$ następnie ujęte $w$ wykazie terenów mających znaczenie dla Wspólnoty przyjętym decyzja Komisji 2006/613/WE z dnia 19 lipca 2006 r. przyjmująca na mocy dyrektywy Rady 92/43/EWG wykaz podlegających ochronie terenów śródziemnomorskiego regionu biogeograficznego majacych znaczenie dla Wspólnoty byty objęte, po notyfikacji tej decyzji zainteresowanemu państwu członkowskiemu, zakresem ochrony przewidzianym $w$ tej dyrektywie, jeszcze zanim wspomniana decyzja została opublikowana. W szczególności, po takiej notyfikacji, zainteresowane państwo członkowskie było również zobowiązane podjać środki ochronne przewidziane $w$ art. 6 ust. 2-4 tej dyrektywy.

7) Wykładni dyrektywy 92/43, a w szczególności jej art. 6 ust. $3 i 4$, należy dokonywać $w$ ten sposób, że stoi ona na przeszkodzie temu, aby na realizacje projektu przekie- 
rowania wód, który nie jest konieczny dla zachowania obszaru specjalnej ochrony lub bezpośrednio z zachowaniem go związany, ale który może na ten obszar specjalnej ochrony $w$ istotny sposób oddziatywać, wydane zostato pozwolenie, jeśli brak jest informacji lub wiarygodnych $i$ aktualnych danych dotyczacych ptactwa występujacego na tym obszarze.

8) Wykładni dyrektywy 92/43 należy dokonywać $w$ ten sposób, że powody przyjęcia projektu przekierowania wód, zwiąane po pierwsze, z nawadnianiem $i$, po drugie, z zapotrzebowaniem na wode pitna, moga stanowić nadrzędny interes publiczny uzasadniający realizacje przedsięwzięcia wywierajaccego negatywny wptyw na integralność terenów, których ono dotyczy. Jeżeli przedsięwzięcie to narusza integralność terenu majacego znaczenie dla Wspólnoty obejmującego typ siedliska przyrodniczego lub zamieszkanego przez gatunek o znaczeniu priorytetowym, jego realizacja może co do zasady być uzasadniona względami zwiazanymi z zapotrzebowaniem na wode pitna. Natomiast nawadnianie nie należy, co do zasady, do względów odnoszacych się do zdrowia ludzkiego i bezpieczeństwa publicznego, uzasadniających przedsięwzięcie takie jak projekt sporny $w$ postępowaniu przed sądem krajowym.

9) Zgodnie z dyrektywą 92/43, a w szczególności z jej art. 6 ust. 4 akapit pierwszy zdanie pierwsze, dla ustalenia, czy środki kompensujące sq odpowiednie, należy wziać pod uwage zasięg przekierowania wód i zakres prac, którego ono wymaga.

10) Dyrektywa 92/43, a w szczególności jej art. 6 ust. 4 akapit pierwszy, interpretowana $w$ świetle celu polegajacego na zrównoważonym rozwoju, ustanowionego $w$ art. 6 WE, zezwala $w$ odniesieniu do obszarów wchodzacych $w$ skład sieci Natura 2000 na przeksztatcenie naturalnego ekosystemu rzecznego $w$ stworzony przez człowieka ekosystem rzeczny i jeziorny, o ile spetnione sa przestanki określone $w$ tym przepisie dyrektywy. 


\subsubsection{Wyrok Trybunału z dnia 4 października 2012 r. w sprawie C-403/11 Komisja Europejska przeciwko Królestwu Hiszpanii ${ }^{25}$}

Przedmiot: uchybienie zobowiązaniom państwa członkowskiego; naruszenie art. 13 ust. $1-3$ i 6, art. 14 ust. 1 lit. c) i art. 15 ust. 1 dyrektywy 2000/60/WE Parlamentu Europejskiego i Rady z dnia 23 października 2000 r. ustanawiającej ramy wspólnotowego działania w dziedzinie polityki wodnej (Dz.U. L 327, s. 1); plany gospodarowania wodami w dorzeczu; informowanie społeczeństwa i konsultacje; przekazywanie tych planów gospodarowania.

Sentencja:

1) Królestwo Hiszpanii:

- nie przyjmując do dnia 22 grudnia 2009 r. planów gospodarowania wodami $w$ dorzeczu, z wyjątkiem przypadku Distrito de la Cuenca Fluvial de Cataluña (okręgu dorzecza Katalonii), i nie przekazując Komisji oraz innym zainteresowanym państwom członkowskim do dnia 22 marca 2010 r. kopii tych planów zgodnie z art. 13 ust. 1-3 i 6 oraz art. 15 ust. 1 dyrektywy 2000/60/ WE Parlamentu Europejskiego i Rady z dnia 23 października 2000 r. ustanawiającej ramy wspólnotowego działania $w$ dziedzinie polityki wodnej, zmienionej dyrektywą Parlamentu Europejskiego i Rady 2008/32/ WE z dnia 11 marca 2008 r. oraz

- nie wszczynajac procedur dotyczacych informowania społeczeństwa $i$ konsultacji $w$ przedmiocie planów gospodarowania wodami $w$ dorzeczu najpóźniej do dnia 22 grudnia 2008 r. zgodnie z art. 14 ust. 1 lit. c) tej dyrektywy, z wyjątkiem okręgów dorzecza Katalonii, Balearów, Teneryfy, Gwadiany, Gwadalkiwiru, Cuenca Mediterránea Andaluza (andaluzyjskiego basenu Morza Śródziemnego), Tinto-Odiel-Piedras, Guadalete-Barbate, Galicia-Costa, Miño-Sil, Duero, Cantábrico Occidental oraz Cantábrico Oriental, uchybiło zobo- 
wiązaniom ciążcym na nim na mocy wymienionych przepisów.

2) Królestwo Hiszpanii zostaje obcią̇one kosztami postępowania.

\subsubsection{Wyrok Trybunału z dnia 13 czerwca 2013 r. w sprawie C-193/12 Komisja Europejska przeciwko Republice Francuskiej ${ }^{26}$}

Przedmiot: uchybienie zobowiązaniom państwa członkowskiego, naruszenie art. 3 ust. 1 i 4 oraz załącznika I do dyrektywy Rady 91/676/EWG z dnia 12 grudnia 1991 r. dotyczącej ochrony wód przed zanieczyszczeniami powodowanymi przez azotany pochodzenia rolniczego (Dz.U. L 375, s. 1); niekompletne wskazanie stref zagrożenia; nadmierna zawartość azotanów; eutrofizacja; odbywający się co cztery lata nieprawidłowy przegląd.

Sentencja:

1) Nie wyznaczając szeregu stref charakteryzujących się obecnościa zbiorników wód powierzchniowych i gruntowych dotkniętych nadmierna zawartościa azotanów lub zjawiskiem eutrofizacji lub zagrożeniem ich wystapienia jako stref zagrożenia, Republika Francuska uchybiła zobowiązaniom ciążacym na niej na mocy art. 3 ust. 1 i 4 dyrektywy Rady 91/676/EWG z dnia 12 grudnia 1991 r. dotyczącej ochrony wód przed zanieczyszczeniami powodowanymi przez azotany pochodzenia rolniczego oraz załacznika I do tej dyrektywy.

2) Republika Francuska zostaje obciążona kosztami postępowania. 


\subsubsection{Wyrok Trybunału z dnia 24 października 2013 r. w sprawie C-151/12 Komisja Europejska przeciwko Królestwu Hiszpanii ${ }^{27}$}

Przedmiot: naruszenie art. 4 ust. 8, art. 7 ust. 2, art. 10 ust. 1 i 2 dyrektywy 2000/60/WE Parlamentu Europejskiego i Rady z dnia 23 października 2000 r. ustanawiającej ramy wspólnotowego działania w dziedzinie polityki wodnej (Dz.U. L 327, s. 1) oraz pkt 1.3 i 1.4 załącznika V do niej; cele ochrony środowiska; wody wykorzystywane do poboru wody do spożycia; wody powierzchniowe; zlewnie wewnątrzwspólnotowe.

Sentencja:

1) Nie podejmując wszystkich środków niezbędnych do dokonania transpozycji art. 4 ust. 8, art. 7 ust. 2, art. 10 ust. 1 i 2 dyrektywy 2000/60/WE Parlamentu Europejskiego i Rady z dnia 23 października 2000 r. ustanawiajacej ramy wspólnotowego działania $w$ dziedzinie polityki wodnej oraz pkt 1.3 i 1.4 .1 ppkt (i)-(iii) załacznika $V$ do niej, do którego to załącznika odsyła art. 8 ust. 2 tej dyrektywy $w$ odniesieniu do zlewni wewnątrzwspólnotowych położonych poza terytorium Katalonii oraz art. 7 ust. 2 i art. 10 ust. 1 i 2 dyrektywy 2000/60 w odniesieniu do zlewni wewnątrzwspólnotowych położonych na terytorium Katalonii, Królestwo Hiszpanii uchybiło zobowiązaniom ciążacym na nim na mocy tej dyrektywy.

2) W pozostałym zakresie skarga zostaje oddalona.

3) Królestwo Hiszpanii zostaje obciążone kosztami postępowania.

\subsection{OCHRONA POWIETRZA}

2.7.1. Wyrok Trybunału z dnia 15 listopada 2012 r. w sprawie C-34/11 Komisja Europejska przeciwko Republice Portugalskiej ${ }^{28}$

Przedmiot: uchybienie zobowiązaniom państwa członkowskiego; naruszenie art. 13 dyrektywy Parlamentu Europej- 
skiego i Rady 2008/50/WE z dnia 21 maja 2008 r. w sprawie jakości powietrza i czystszego powietrza dla Europy (Dz.U. L 152, s. 1); wartości dopuszczalne i progi alarmowe w zakresie ochrony zdrowia ludzkiego; stężenie PM10 w otaczającym powietrzu.

Sentencja:

1) Nie gwarantujacc, ̇̇e na lata 2005-2007 stężenie PM10 $w$ otaczajacym powietrzu nie przekroczy wartości dopuszczalnych określonych $w$ art. 5 ust. 1 dyrektywy Rady 1999/30/WE z dnia 22 kwietnia 1999 r. odnoszacej się do wartości dopuszczalnych dla dwutlenku siarki, dwutlenku azotu i tlenków azotu oraz pyłu i ołowiu w powietrzu, w odniesieniu do stref $i$ aglomeracji Bragi, nadbrzezy Porto, obszaru metropolitalnego Lizbona-Pótnoc oraz obszaru metropolitalnego Lizbona-Potudnie, Republika Portugalska uchybiła zobowiązaniom państwa członkowskiego ciążcym na niej na mocy tego przepisu.

2) W pozostałym zakresie skarga zostaje oddalona.

3) Komisja Europejska i Republika Portugalska pokrywaja własne koszty.

\subsubsection{Wyrok Trybunału z dnia 19 grudnia 2012 r. w sprawie C-68/11 Komisja Europejska przeciwko Republice Włoskiej ${ }^{29}$}

Przedmiot: uchybienie zobowiązaniom państwa członkowskiego; naruszenie art. 5 ust. 1 dyrektywy Rady 1999/30/ WE z dnia 22 kwietnia 1999 r. odnoszącej się do wartości dopuszczalnych dla dwutlenku siarki, dwutlenku azotu i tlenków azotu oraz pyłu i ołowiu w otaczającym powietrzu (Dz.U. L 163, s. 41, obecnie art. 13 ust. 1 dyrektywy Parlamentu Europejskiego i Rady 2008/50/WE z dnia 21 maja 2008 r. w sprawie jakości powietrza i czystego powietrza dla Europy, Dz.U. L 152, s. 1); przekroczenie dopuszczalnych wartości stężenia pyłu PM10 w powietrzu od $2005 \mathrm{r}$. 
Sentencja:

1) Nie zapewniajacc, aby w latach 2006 i 2007 stężenie PM10 $w$ otaczajacym powietrzu $w 55$ wtoskich strefach i aglomeracjach wskazanych $w$ wystosowanym przez Komisje Europejska $w$ dniu 2 lutego 2009 r. wezwaniu do usunięcia uchybienia nie przekraczało wartości dopuszczalnych określonych $w$ art. 5 ust. 1 dyrektywy Rady 1999/30/ /WE z dnia 22 kwietnia 1999 r. odnoszacej się do wartości dopuszczalnych dla dwutlenku siarki, dwutlenku azotu i tlenków azotu oraz pyłu i ołowiu $w$ otaczajacym powietrzu, Republika Włoska uchybiła zobowiąaniom cią̇acym na niej na mocy tego przepisu.

2) W pozostałym zakresie skarga zostaje oddalona.

3) Komisja Europejska i Republika Wtoska pokrywaja własne koszty.

\subsection{ZAGADNIENIA POZOSTAEE}

\subsubsection{Biopaliwa - Wyrok Trybunału z dnia 31 stycznia 2013 r.} w sprawie C-26/11 Belgische Petroleum Unie VZWi in. przeciwko

Belgische Staat ${ }^{30}$ (wniosek o wydanie orzeczenia w trybie prejudycjalnym złożony przez Grondwettelijk Hof, Belgia)

Przedmiot: wykładnia art. 4 ust. 3 TUE, art. 26 ust. 2, art. 28, 34, 35 i 36 TFUE, art. 3, 4 i 5 dyrektywy 98/70/WE Parlamentu Europejskiego i Rady z dnia 13 października 1998 r. odnoszącej się do jakości benzyny i olejów napędowych oraz zmieniającej dyrektywę Rady 93/12/EWG (Dz.U. L 350, s. 58) oraz art. 8 dyrektywy 98/34/WE Parlamentu Europejskiego i Rady z dnia 22 czerwca 1998 r. ustanawiającej procedurę udzielania informacji w dziedzinie norm i przepisów technicznych oraz zasad dotyczących usług społeczeństwa informacyjnego (Dz.U. L 204, s. 37); przepisy krajowe nakładające na wprowadzające do obrotu benzynę lub olej napędowy spółki przemysłu nafto-

30 Dz.Urz. UE C 86 z 23.03.2013. 
wego obowiązek wprowadzenia w tym samym roku do obrotu również pewnej ilości bioetanolu, czystego bądź w formie bio-ETBE, oraz pewnej ilości estrów metylowych kwasów tłuszczowych (FAME).

Sentencja:

1) Artykuty 3-5 dyrektywy 98/70/WE Parlamentu Europejskiego i Rady z dnia 13 października 1998 r. odnoszącej się do jakości benzyny i olejów napędowych oraz zmieniajacej dyrektywę Rady 93/12/EWG, zmienionej dyrektywa 2009/30/WE Parlamentu Europejskiego i Rady z dnia 23 kwietnia 2009 r., należy interpretować w ten sposób, że nie stoją one na przeszkodzie przyjęciu przepisu krajowego takiego jak rozpatrywany $w$ postępowaniu głównym, który - realizując wyznaczony państwom członkowskim $w$ dyrektywie 2003/30/WE Parlamentu Europejskiego i Rady z dnia 8 maja 2003 r. w sprawie wspierania użycia $w$ transporcie biopaliw lub innych paliw odnawialnych, $w$ dyrektywie Parlamentu Europejskiego i Rady 2009/28/ WE $\%$ dnia 23 kwietnia 2009 r. $w$ sprawie promowania stosowania energii ze źródeł odnawialnych zmieniajacej $i$ wastepstwie uchylajacej dyrektywy 2001/77/WE oraz 2003/30/WE, a takize $w$ dyrektywie 2009/30 cel polegający na wspieraniu stosowania biopaliw $w$ sektorze transportowym - nakłada na wprowadzajace do obrotu benzynę lub olej napędowy spótki przemysłu naftowego obowiąek wprowadzenia $w$ tym samym roku kalendarzowym do obrotu również pewnej określonej, domieszanej do tych produktów, ilości biopaliw, jeśli ilość ta jest obliczana jako określona $w$ procentach część tych produktów łacznie wprowadzanych przez te spótki do obrotu $w$ ciagu roku, a te określone $w$ procentach wartości sa zgodne z dopuszczalnymi wartościami maksymalnymi określonymi w dyrektywie 98/70, zmienionej dyrektywa 2009/30.

2) Artykut 8 dyrektywy 98/34/WE Parlamentu Europejskiego i Rady z dnia 22 czerwca 1998 r. ustanawiającej procedurę udzielania informacji $w$ dziedzinie norm i przepisów technicznych oraz zasad dotyczących ustug społeczeństwa informacyjnego, zmienionej dyrektywa 98/48/WE Par- 
lamentu Europejskiego i Rady z dnia 20 lipca 1998 r., $w$ zwiazku z art. 10 ust. 1 tiret ostatnie tej dyrektywy należy interpretować $w$ taki sposób, że nie ustanawia on obowiązku zgłaszania projektów przepisów krajowych zobowiązujących wprowadzające do obrotu benzynę lub olej napędowy spótki przemystu naftowego do wprowadzenia $w$ tym samym roku kalendarzowym do obrotu również pewnej określonej w procentach ilości biopaliw, jeśli wskutek dokonanego $w$ zastosowaniu tego art. 8 ust. 1 akapit pierwszy zgłoszenia ten projekt przepisów został zmieniony $w$ sposób uwzględniający przedstawione przez Komisję Europejska $w$ jego przedmiocie uwagi, a następnie zmieniony $w$ ten sposób projekt został podany do wiadomości tej instytucji.

\subsubsection{Energetyka i órodowisko - Wyrok Trybunału z dnia 26 wrzeónia 2013 r. w sprawie C-195/12 Industrie du bois de Vielsalm \& Cie (IBV) SA przeciwko Région wallonne ${ }^{31}$ (wniosek o wydanie orzeczenia} w trybie prejudycjalnym złożony przez Cour constitutionnelle, Belgia)

Przedmiot: wykładnia art. 7 dyrektywy 2004/8/WE Parlamentu Europejskiego i Rady z dnia 11 lutego 2004 r. w sprawie promowania kogeneracji $\mathrm{w}$ oparciu o zapotrzebowanie na ciepło użytkowe na rynku wewnętrznym energii oraz zmieniającej dyrektywę 92/42/EWG (Dz.U. L 52, s. 50); wykładnia art. 2 i 4 dyrektywy 2001/77/WE Parlamentu Europejskiego i Rady z dnia 27 września 2001 r. w sprawie wspierania produkcji na rynku wewnętrznym energii elektrycznej wytwarzanej ze źródeł odnawialnych (Dz.U. L 283, s. 33); wykładnia art. 22 dyrektywy Parlamentu Europejskiego i Rady 2009/28/WE z dnia 23 kwietnia 2009 r. w sprawie promowania stosowania energii ze źródeł odnawialnych zmieniającej i w następstwie uchylającej dyrektywy 2001/77/WE oraz 2003/30/WE (Dz.U. L 140, s. 16); wykładnia art. 6 TUE oraz art. 20 i 21 Karty praw podstawowych

31 Dz.Urz. UE C 344 z 23.11.2013. 
Unii Europejskiej; systemy wsparcia finansowego ograniczone do wysokosprawnych instalacji do kogeneracji; obowiązek, dopuszczenie albo zakaz wyłączenia ze środków wsparcia instalacji do kogeneracji przetwarzających głównie drewno lub odpady drzewne; zgodność uregulowania z zasadą równości.

\section{Sentencja:}

1) Artykut 7 dyrektywy 2004/8/WE Parlamentu Europejskiego i Rady z dnia 11 lutego 2004 r. $w$ sprawie promowania kogeneracji w oparciu o zapotrzebowanie na ciepto użytkowe na rynku wewnętrznym energii oraz zmieniającej dyrektywę 92/42/EWG należy interpretować $w$ ten sposób, że zakres jego stosowania nie jest ograniczony tylko do tych instalacji do kogeneracji, które charakteryzuja się tym, że sq wysokosprawnymi instalacjami $w$ rozumieniu tej dyrektywy.

2) Na obecnym etapie prawa Unii zasada równego traktowania i niedyskryminacji, wyrażona $w$ szczególności $w$ art. 20 i 21 Karty praw podstawowych Unii Europejskiej, nie sprzeciwia się temu, aby przy ustanawianiu krajowych systemów wspierania kogeneracji i wytwarzania energii elektrycznej pochodzacej z odnawialnych źródet energii, takich jak te, których dotyczy art. 7 dyrektywy 2004/8 $i$ art. 4 dyrektywy 2001/77 Parlamentu Europejskiego i Rady z dnia 27 września 2001 r. w sprawie wspierania produkcji na rynku wewnętrznym energii elektrycznej wytwarzanej ze źródeł odnawialnych, państwa członkowskie przewidziaty środek wzmożonego wsparcia, taki jak ten, którego dotyczy postępowanie główne, z którego to środka moga korzystać wszystkie instalacje do kogeneracji przetwarzające głównie biomasę, z wykluczeniem instalacji do kogeneracji przetwarzajacych gtównie drewno lub odpady drzewne. 